SECTION 21. Pedagogy. Psychology. Innovations in the field of education.

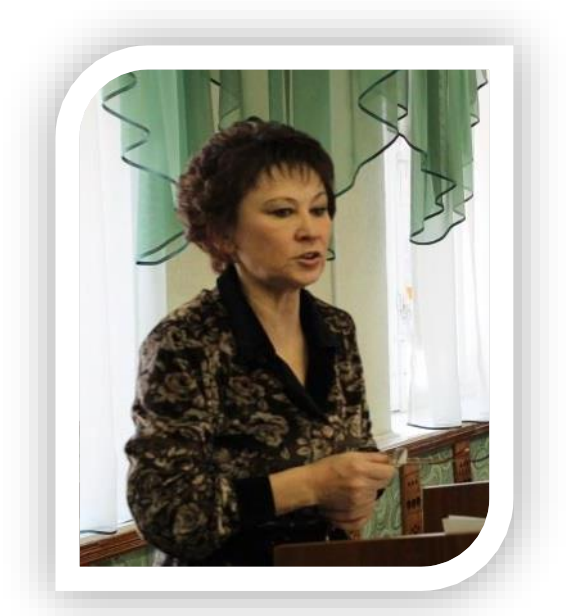

\author{
Akhmadeyeva Neylya Tavafovna \\ The teacher of initial classes of the first category \\ Gymnasium №40, Taraz, Kazakhstan
}

\title{
TECHNOLOGICAL APPROACHES TO THE DEVELOPMENT OF EDUCATIONAL AND LOGICAL SKILLS OF SCHOOLCHILDREN
}

\begin{abstract}
The paper studies the technological approaches in training. In the process of use of technological approaches for development of educational and logical skills develop intellectual qualities and striving for creative activity. This work helps children learn how to allocate the main thing in a studied material, analyze, generalize and systematize the selected information, to find the most rational methods of solving theoretical and practical problems, to perceive critically the results and apply them in the future.
\end{abstract}

Key words: technological approach, training, methods of teaching.

\section{ТЕХНОЛОГИЧЕСКИЕ ПОДХОДЫ ПО РАЗВИТИЮ УЧЕБНО-ЛОГИЧЕСКИХ УМЕНИЙ И НАВЫКОВ У ШКОЛЬНИКОВ}

Аннотация: В работе исследуются технологические подходы в обучении. В процессе использования технологических подходов по развитию учебно-логических умений и навыков развиваются интеллектуальные качества и стремление к творческой деятельности. Такая работа помогает научить детей самостоятельно выделять главное в изучаемом материале, анализировать, обобщать и систематизировать отобранную информацию, находить наиболее рачиональные приёмы решения теоретических и практических задач, критически осмысливать полученные результаты и применять их в дальнейтем.

Ключевые слова: технологический подход, обучение, методика обучения.

Один из важнейших факторов развития интереса к учению - это чёткое понимание детьми необходимости того или иного изучаемого материала. Все познавательные процессы эффективно развиваются при такой организации обучения, когда учащиеся включаются в активную поисковую деятельность. Поиск нового составляет основу для развития воли, внимания, памяти, воображения и мышления. В обучении особое значение в этой связи приобретает исследовательская деятельность учащихся, непосредственно связанная с усвоением знаний. В процессе использования технологических подходов по развитию учебно-логических умений и навыков у школьников развиваются все интеллектуальные качества и стремление к творческой деятельности. Такая работа помогает научить детей самостоятельно выделять главное в изучаемом материале, анализировать, обобщать и систематизировать отобранную информацию, находить наиболее рациональные приёмы решения теоретических и 
практических задач, критически осмысливать полученные результаты и применять их в дальнейшем. В своей работе над развитием логического мышления я определила цель повысить эффективность обучения, расширить и обогатить знания с помощью заданий познавательного характера, которые бы способствовали мотивации к учению, умению применять знания на практике.

Главной задачей для достижения цели является: научить ребят анализировать, сравнивать, экспериментировать, делать вывод. И цель и задача направлены на развитие познавательных процессов, способствующих повышению качества знаний, умений, проявлению интереса к предмету. Сегодня я хотела бы поделиться опытом своей работы развития логического мышления на уроках в начальной школе.

Философы утверждают, что всё во Вселенной построено на ритме. Ритмы и рифмы позволяют лучше усваивать изучаемый материал. Так, для мобилизации внимания используем рифмованные начала уроков.

Начинается урок,

Долгожданный дан звонок -

Он пойдёт ребятам впрок.

Начинается урок!

Постараюсь всё понять -

Буду грамотно писать!

Начинаем урок с элементов театрализации. Путешествуем по различным станциям, соревнуемся.

Математика даёт реальные возможности для развития мышления и воображения. Традиционно проблема развития познавательного интереса ребёнка решается через применение занимательного материала, яркие наглядные пособия. Ещё Ян Амос Коменский призывал сделать труд школьника источником умственного удовлетворения и душевной радости.

На уроках учимся подмечать закономерности, сходства и различия простых упражнений. При изучении темы «Нумерация чисел в пределах 100» предлагаем такие задания:

1) Установи закономерность и продолжи ряд чисел:

a) $3,5,7,9, \ldots$

$1,4,7,10, \ldots$

$10,30,50,70, \ldots$

$14,34,74, \ldots$

б) $40,20,60, \ldots$

$10,80,90, \ldots$

$20,70,40, \ldots$

$80,10,70, \ldots$

$70,10, \ldots$

$30,20,0, \ldots$

$30,20,10, \ldots$

$50,90, \ldots$

$60,20, \ldots$

2) Сравни числа первого и второго рядов. Найди сумму чисел первого ряда, второго ряда:

\section{$\begin{array}{lllll}3 & 4 & 5 & 6 & 7\end{array}$ \\ $13 \quad 14 \quad 15 \quad 16 \quad 17$}

3) Вставь подходящие числа, не нарушая равенства: $\ldots-6=6+\ldots$

Чередуем математические задания с информацией о животных и событиях - это позволяет усилить воспитательный эффект урока, осуществить межпредметные связи.

4) а) Какая птица может ходить по дну водоёма?

Воробей -3

Решив цепочку примеров, узнаете правильный ответ:

Оляпка -4 $8-6+7-6+5-4=\ldots$

Сорока -5

Задаём дополнительные вопросы: 
Сколько слогов в слове? Из каких звуков состоит каждый слог? В каком рассказе встречается эта птица? Как помогает животным?

Оляпка - певчая птица бурого цвета с белой грудкой. Она может нырять и бегать по дну водоёма. На дне ловит насекомых, червей и маленьких рыб. Пойманную добычу всегда выносит на берег и съедает. Спасаясь от врагов, ныряет в воду.

б) Какая рыба без чешуи?

$$
\begin{aligned}
& \text { Щука - } 4 \\
& \text { Сом - } 2 \\
& \text { Карась - } 3
\end{aligned}
$$

$$
\ldots+8-9+8-6+4=7 \quad \text { (ответ } 2)
$$

в) Из какой сказки эти слова: «А дорога далека, а корзина нелегка. Сесть бы на пенёк, съесть бы пирожок»?

$$
\begin{array}{lll}
\text { «Три медведя» } & -8 & 8-4+5-7=\ldots \\
\text { «Маша и медведь» - } 6 & 8-1+3-6=\ldots \\
\text { «Медведь» - } &
\end{array}
$$

г) Белка очень запасливый зверёк. Неподалеку от своего дома устраивает кладовки, где хранит орехи, жёлуди, шишки. Грибы накалывает на тонкие сухие веточки. Неизвестно, что случилось, только белка заблудилась. Ищет белочка свой дом, и мы сейчас его найдем. Где живёт белка?

$$
\begin{aligned}
& \text { В норе - } 3 \\
& \text { В дупле - } 5 \\
& \text { В гнезде - } 7
\end{aligned}
$$

Какое число надо вставить в клетку, чтобы квадрат стал магическим?

\begin{tabular}{|l|l|l|}
\hline 2 & 7 & 6 \\
\hline 9 & & 1 \\
\hline 4 & 3 & 8 \\
\hline
\end{tabular}

В логической последовательности подвожу ребят к устному счету, где использую задания познавательного характера, задачи, которые включают в себя сюжеты из литературных произведений, сказочные сюжеты, задания, где необходимо выстраивать цепочку суждений. Приведу примеры таких задач и заданий:

1) С хозяйством попа справляется 10 работников. Каждый работник съедает в день каравай хлеба и другие продукты. Поп принял на работу Балду. Живёт Балда в поповом доме, спит на соломе, ест за четверых, работает за семерых. Поп прогнал лишних работников. Сколько караваев хлеба экономил поп ежедневно?

2) Замени словесную запись числовой.

Из числа разбойников Али-Бабы вычесть число богатырей братьев Царевны-Лебеди.

3) - Батон разрезали на три части. Сколько сделали разрезов?

- Бублик разрезали на четыре части. Сколько сделали разрезов?

- Четыре мальчика купили шесть тетрадей. Каждому мальчику досталось не менее одной тетради. Мог ли какой-нибудь мальчик купить три тетради?

Для формирования умения проводить дедуктивные рассуждения используем такие задания:

- Пианино - музыкальный инструмент. У Вовы дома музыкальный инструмент. Значит, у него дома пианино?

- Классные комнаты надо проветривать. Квартира - это не классная комната. Значит, квартиру не надо проветривать?

- Верно ли, что 25 см больше, чем 2 дм 5 см?

Применение приёма классификации на уроках математики позволяет расширить имеющиеся в практике приёмы работы, способствует формированию положительных мотивов в учебной деятельности, т.к. подобная работа содержит элементы игры, 
поисковой деятельности, повышает активность, обеспечивает самостоятельность выполнения работ.

- Разбей данные числа на две группы: числа, которые меньше 5; числа, которые больше 5: $1,2,3,4,5,6,7$.

- Разбей выражения на группы по одинаковым признакам: $13+1,14-1,15+1$, $16-1,17+1,18-1$.

- Определи признак, по которому можно было бы разделить данные числа на две группы: $2,7,35,41,4,8,60,80,3$ и т.д.

- Выпиши все числа, которые записаны двумя различными цифрами:

$22,56,80,66,74,47,88,31,94,44$. Посмотри на оставшиеся числа, назови общий для них признак.

- Исключи элементы, не относящиеся к группе элементов, докажи:

дм, см, м, л;

Приставка, предлог, суффикс, окончание;

Дождь, снег, осадки, иней, град;

Василий, Самат, Наргиз, Петров.

Учащиеся учатся обосновывать свои суждения, формировать навыки самостоятельной работы над задачами, сознательно использовать приобретённые знания. Наша работа направлена на сознательное усвоение учениками общего вывода, свойства и закономерности. Например, при решении задач:

- В одной книге 36 страниц, а в другой 30 страниц. На сколько страниц в первой книге больше, чем во второй? Рассуждение строится таким образом: все задачи, в которых требуется узнать на сколько одно число больше или меньше другого, решаются действием вычитания. В этой задаче нужно узнать, на сколько 36 больше, чем 30. Вывод: нужно от 36 отнять 30.

В процессе обучения рассуждениям побуждаем учащихся к поискам правильных ответов.

- Вставь пропущенное число. 1, 3, 7, 13,_... Ответ: 21, 31. Последовательно прибавляем к числу чётные в порядке возрастания.

- Определи закономерность, найди пропущенные числа:

\begin{tabular}{|l|l|}
\hline 8 & 2 \\
\hline 4 & 10 \\
\hline \multicolumn{2}{|l}{} \\
\hline 1 & 5 \\
\hline 12 & $?$ \\
\hline \multicolumn{2}{|l}{} \\
\hline 2 & 3 \\
\hline 3 & $?$ \\
\hline
\end{tabular}

$$
4+8-2=10
$$$$
12+1-5=8
$$

$3+2-3=2$

Для формирования навыков анализа и синтеза предлагаем учащимся следующие задания на уроках русского языка:

- Разбери слово по составу.

- К данной схеме подбери как можно больше слов (имеющих в своем составе корень и суффикс). окамндри...

- Анаграммы (преобразование букв путём их перестановки в слово): луфобт,

- Шестиклеточный логикон:

\begin{tabular}{|c|c|c|c|}
\hline слон & com & уж & \multirow{4}{*}{$\begin{array}{l}\text { Буква «з»: уж - змея. } \\
\text { Буква «Л»: морㅆ, клад, клуб. }\end{array}$} \\
\hline ж & $\mathrm{p}$ & $?$ & \\
\hline морж & клад & клуб & \\
\hline Ж & $\mathrm{a}$ & $?$ & \\
\hline
\end{tabular}




\begin{tabular}{|c|c|c|}
\hline белый & Hoc & Сел \\
\hline$\Pi$ & $\mathrm{C}$ & $?$ \\
\hline
\end{tabular}

- Заполни недостающие буквы в слове:

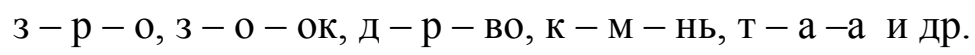

Работая над развитием навыка обобщения, предлагаем следующие упражнения!

- Найди общий признак:

школа - учитель, дождь - град, нос - глаз, литература - математика

a) Все имена существительные изменяются по числам. Слово урок - имя существительное, следовательно, оно изменяется по числам.

б) Все растения поглощают на свету углекислый газ. Тополь - растение, следовательно,...

в) Все названия рек пишутся с прописной буквы. Каргала - река, следовательно, ...

-Найди общее продолжение для всех слов: д..., л..., п..., т..., ос... (...ень) Для развития навыка конкретизации применяем такие виды заданий:

1) На уроках русского языка предлагаем детям составить предложения из четырёх слов, каждое из которых начинается с указанной буквы. Например:

М В Ч О - Мастер Владимир чинит обувь.

Маша Витю чаем облила.

В С Н Т - Весной снег начинает таять.

Весёлый Серёжа начал топать.

2) На уроках литературного чтения придумываем с детьми как можно больше заглавий к тексту.

3) «Сокращение рассказа» - зачитывается рассказ, учащиеся должны передать содержание текста 2 - 3 предложениями, сохраняя основное содержание.

4) «Поиск способов применения». Учащиеся называют как можно больше способов применения указанного предмета.

5) «Знаете ли вы пословицу?» Необходимо вспомнить пословицу по двум её словам:

Время - потеха. Дело - мастера. Друга - береги. $\quad$ Гоп - перепрыгнешь. пруда. Каравай - не зевай. Калачи - на печи. Знать - учиться.

Для формирования навыка сравнения используем следующие задания:

-Выбери из предложенных пословиц противоположную пословицу или аналогичную по смыслу:

Один в поле не воин. Теперь обувь шьют без шила. Трудно и дереву одинокому расти. О книге не суди по переплёту. Чистое золото ценится дорого.

- «Укрась слово». К предложенному имени существительному подобрать как можно больше подходящих по смыслу имён прилагательных. Например:

Задача - простая, сложная, трудная, лёгкая, непонятная, взаимообратная...

Снег - зимний, весенний, последний, искристый, мокрый, колючий, грязный, пушистый, серебристый, лёгкий, рыхлый, белый, свежий...

- «Зелёные слова» - лягушка, огурец, трава, крокодил, кузнечик...

- «Прыгающие слова» - лягушка, кенгуру, заяц, кузнечик...

Воображение и фантазия присущи каждому человеку, но люди различаются направленностью фантазии, её силе, яркости. Одним из приёмов развития данных качеств являются следующие упражнения:

- Воссоздание образов художественного произведения. После первого прочтения дети должны нарисовать те предметы, о которых идёт речь. Передать 
цвет, размер, форму, расположение. После этого разрешается внимательно перечитать текст и сделать второй рисунок.

Тренировкой воображения, а вместе с ним и мышления, внимания, памяти и других, связанных с ними функций, обслуживающих учебную деятельность, являются игры и задания, имеющие не единственное решение.

1) Составление изображений объектов. Нарисовать лицо, клоуна, домик, кошку, дождь, пользуясь только данным набором фигур (круг, прямоугольник, треугольник, трапеция). Каждую фигуру можно использовать многократно, менять её размеры. Однако, нельзя добавлять другие фигуры или линии.

2) Незаконченные рисунки. Учащиеся должны догадаться, какой предмет изображён по неполным контурам.

3) Заполнение отсутствующих деталей на рисунке по тесту Равена.

4) Нелепые картинки. Найти несоответствие в предложенном изображении.

Умение правильно формулировать посылки и выводить следствия являются важнейшим условием для успешной учёбы. Предлагаем ряд вопросов, начинающихся со слов «что произойдёт, если ...». Учащиеся должны дать как можно больше оригинальных и полных ответов. Например, что произойдёт, если дождь будет лить не переставая? Что произойдёт, если звери заговорят человеческим голосом?

Любое обучение связано с необходимостью что-то представить, вообразить, оперировать абстрактными образами и понятиями. Всё это невозможно сделать без воображения и фантазии. Учащиеся младших классов любят заниматься художественным творчеством. Оно позволяет ребёнку более полно раскрыть свою личность. Вся художественная деятельность строится на активном воображении, творческом мышлении. На уроках изобразительного искусства не только рисуем, но придумываем истории, занимаемся монотипией.

Каждый ребёнок имеет свои, только ему присущие черты, которые могут быть распознаны достаточно рано. В этом помогают родители. Проводя работу с родителями, ориентируемся на раскрытие следующих качеств: способность к рисованию, гибкость и быстрота мышления и действий, способность высказывать оригинальные идеи, изобретать новое, развитие интуиции.

В данной работе представлены лишь общие аспекты активизации познавательной деятельности. Однако, существует много других игр и методов для диагностики и развития познавательных процессов. Но предложенные формы можно многократно варьировать, изменять, модифицировать.

\section{Литература:}

1. Журналы «Начальная школа» за 1989 г.

2. Макаренко А.С. О воспитании, Москва - 1985 г. -112c.

3. Амонашвили Ш.А. Здравствуйте дети! Москва - 1987г. -208c.

4. В.А. Крутецкий. «Психология обучения и воспитания школьников» Москва - 2002. 304c.

5. Дубровина И.В. О преподавании психологии в школе // Вопросы психологии. 2005. № 6. С. 46-54.

6. М. Котэ, А.Б. Орлов // Журнал практического психолога. № 3. 1997. С. 66.

7. Лызь И.А. Теоретические основы психологического образования // Психология в вузе. 2004. № 1. С. 113-122.

8. Мироненко И.А. Поп-психология, или о пользе наук // Вопросы психологии. 2008. № 2. С. 103-108. 